\title{
Anaerobic Ammonium Oxidation in Acidic Red Soils
}

\author{
Jiapeng $\mathrm{Wu}^{1,2}$, Yiguo Hong ${ }^{3 *}$, Xiang $\mathrm{He}^{3}$, Lijing Jiao ${ }^{1,2}$, Xiaomei Wen ${ }^{3}$, Shuai Chen ${ }^{3}$, \\ Guangshi Chen ${ }^{3}$, Yiben $\mathrm{Li}^{3}$, Tianzheng Huang ${ }^{3}$, Yaohao Hu ${ }^{1,2}$ and Xiaohan Liu ${ }^{3}$

\footnotetext{
' State Key Laboratory of Tropical Oceanography, South China Sea Institute of Oceanology, Chinese Academy of Sciences, Guangzhou, China, ${ }^{2}$ University of Chinese Academy of Sciences, Beijing, China, ${ }^{3}$ School of Environmental Science and Engineering, Guangzhou University, Guangzhou, China
}

\section{OPEN ACCESS}

Edited by:

Hongchen Jiang,

China University of Geosciences

Wuhan, China

Reviewed by:

Wei Xie,

Tongji University, China

Jing Wang

Tianjin Normal University, China Alex Enrich Prast,

Universidade Federal do Rio

de Janeiro, Brazil

*Correspondence:

Yiguo Hong

yghong@gzhu.edu.cn

Specialty section:

This article was submitted to

Terrestrial Microbiology,

a section of the journal

Frontiers in Microbiology

Received: 04 May 2018

Accepted: 21 August 2018 Published: 05 September 2018

Citation:

Wu J, Hong Y, He X, Jiao L, Wen X,

Chen S, Chen G, Li Y, Huang T, Hu Y and Liu $X$ (2018) Anaerobic

Ammonium Oxidation in Acidic Red Soils. Front. Microbiol. 9:2142. doi: 10.3389/fmicb.2018.02142
Anaerobic ammonium oxidation (anammox) has been proven to be an important nitrogen removal process in terrestrial ecosystems, particularly paddy soils. However, the contribution of anammox in acidic red soils to nitrogen loss has not been welldocumented to date. Here, we investigated the activity, abundance, and distribution of anammox bacteria in red soils collected from nine provinces of Southern China. High-throughput sequencing analysis showed that Candidatus Brocadia dominates the anammox bacterial community (93.03\% of sequence reads). Quantification of the hydrazine synthase gene (hzsB) and anammox 16S rRNA gene indicated that the abundance of anammox bacteria ranged from $6.20 \times 10^{6}$ to $1.81 \times 10^{9}$ and $4.81 \times 10^{6}$ to $4.54 \times 10^{8}$ copies per gram of dry weight, respectively. Contributions to nitrogen removal by anammox were measured by a ${ }^{15} \mathrm{~N}$ isotope-pairing assay. Anammox rates in red soil ranged from 0.01 to $0.59 \mathrm{nmol} \mathrm{N} \mathrm{g}^{-1} \mathrm{~h}^{-1}$, contributing $16.67-53.27 \%$ to $\mathrm{N}_{2}$ production in the studied area, and the total amount of removed nitrogen by anammox was estimated at $2.33 \mathrm{Tg} \mathrm{N}$ per year in the natural red soils of southern China. Pearson correlation analyses revealed that the distribution of anammox bacteria significantly correlated with the concentration of nitrate and $\mathrm{pH}$, whereas the abundance and activity of anammox bacteria were significantly influenced by the nitrate and total nitrogen concentrations. Our findings demonstrate that Candidatus Brocadia dominates anammox bacterial communities in acidic red soils and plays an important role in nitrogen loss of the red soil in Southern China.

Keywords: red soils, anaerobic ammonium oxidation, high-throughput sequencing, Candidatus Brocadia, nitrogen removal

\section{INTRODUCTION}

Anaerobic ammonium oxidation (anammox) is a principal microbe-driven process that removes excess $\mathrm{N}$ from an ecosystem and oxidizes $\mathrm{NH}_{4}^{+}$with $\mathrm{NO}_{2}^{-}$or $\mathrm{NO}_{3}^{-}$to form $\mathrm{N}_{2}$ gas under anaerobic autotrophic condition (Mulder et al., 1995). The discovery of anammox challenged the established concept attributing atmospheric dinitrogen gas $\left(\mathrm{N}_{2}\right)$ from fixed nitrogen in the environment to heterotrophic denitrification. The anammox process is mediated by bacteria belonging to the monophyletic order of Candidate Brocadiales, of the phylum Planctomycetes (Jetten et al., 2010). Presently, there are five different genera of anammox bacteria that have been described, including Candidatus Brocadia (Strous et al., 1999; Kartal et al., 2008), Candidatus Jettenia (Quan et al., 2008), 
Candidatus Kuenenia (Schmid et al., 2000), Candidatus Anammoxoglobus (Kartal et al., 2007), and Candidatus Scalindua (Schmid et al., 2003; Kuypers et al., 2005).

Anammox bacteria are broadly distributed in many kinds of natural environments, including aquatic and terrestrial ecosystems. Candidatus Scalindua was almost the only genus found in marine sediments, such as South China Sea (Hong et al., 2011a), Bohai Sea (Dang et al., 2013), and Arabian Sea (Woebken et al., 2008). In contrast to marine environments, all of these genera of anammox bacteria have been detected in soil ecosystems (Wang et al., 2015; Yang et al., 2017). Zhu et al. (2011) found that the 16S rRNA gene sequence of fertilized paddy soil were related to four different genera of anammox bacteria. Anammox bacteria related to Candidatus Brocadia, Kuenenia, and two novel unidentified clusters were found to dominate in the 12 typical paddy soils collected in southern China (Yang et al., 2015). Shen et al. (2017) detected three genera of anammox bacteria by Illumina-based 16S rRNA gene sequencing in a vegetable field, including Candidatus Kuenenia, Brocadia, and Jettenia. Nonetheless, another study showed that anammox bacteria in rice paddy soils were consisted of mainly Candidatus Scalindua (Wang and $\mathrm{Gu}, 2013$ ), which was regarded as the dominant genus in marine environments. In addition, anammox have been reported to be an important nitrogen removal pathway in soil ecosystems, which accounts for $0.4-37 \%$ of the total $\mathrm{N}_{2}$ production in soil ecosystems (Zhu et al., 2011; Yang et al., 2015; Shan et al., 2016, 2018; Xi et al., 2016). Yang et al. (2015) suggested that $\sim 10 \%$ of applied $\mathrm{N}$-based fertilizers was lost via the anammox process. Until now, however, there has been limited evidence for the existence and role of anammox bacteria in acidic and natural red soils.

Red soil is widely distributed and covers an area of nearly $2.04 \times 10^{6} \mathrm{~km}^{2}$ in southern China, accounting for $6.5 \%$ of the total farmland area, and is one of China's most important agricultural soils ( $\mathrm{Xu}$ et al., 2003). On the other hand, red soils are acidic ( $\mathrm{pH}$ : 4.2-5.9), nutrient deficient (total $\mathrm{N}$ ranges from 1.4 to $2.0 \mathrm{~g} \mathrm{~kg}^{-1}$, Total P: $0.6-0.9 \mathrm{~g} \mathrm{~kg}^{-1}$ ), poor in organic matter (ranging from 10 to $100 \mathrm{~g} \mathrm{~kg}^{-1}$ ) and have low water-holding and supplying capacity (Wilson et al., 2004). Fe (total iron: 11.7-148.0 $\mathrm{g} \mathrm{kg}^{-1}$ ) and $\mathrm{Al}$ oxides are often the dominant clay minerals in red soils. Increasing evidence shows that soil characteristics (e.g., soil moisture, $\mathrm{pH}$, and nutrient conditions) may significantly affect the activity and community of soil ammonia oxidation bacteria and archaea (Nicol et al., 2008; Erguder et al., 2009; Gleeson et al., 2010; Gubryrangin et al., 2011; Liu et al., 2017). We hypothesized that the activity, abundance, and diversity of anammox bacteria in red soil would be lower than in other natural habitats. Besides, the anammox population in red soil is expected to be related to a limited number of genera that can be adapted to acidic and nutrientdeficient conditions.

In this study, 10 representative red soil samples from nine provinces of southern China were collected to (i) analyze the diversity and structure of anammox bacteria by Illumina-based 16S rRNA gene sequencing; (ii) determine the abundance of anammox bacteria by quantitative PCR (qPCR) analysis of the hydrazine synthase gene $(h z s B)$ and 16S rRNA gene; (iii) evaluate the potential rates and contribution of anammox and denitrification to $\mathrm{N}_{2}$ production using the ${ }^{15} \mathrm{~N}$-labeling approach; (iv) analyze the relations between the physicochemical characteristics of red soil and activity, abundance, and community structure of anammox bacteria. This study provides a new understanding of the community composition and $\mathrm{N}$ loss contribution of anammox bacteria in non-fertilized acidic red soils.

\section{MATERIALS AND METHODS}

\section{Samples Collection of Red Soil}

A total of 10 red soil samples from nine provinces were collected from the natural fields in southern China (Figure 1 and Table 1) during July 2017. These fields were not affected by a substantial amount of nitrogen fertilizer. Red soil samples (depth: 0-20 cm, Supplementary Figure 1) of four replicates (ca. 500 g each subsample) were collected from 10 natural red soils. Soil samples were immediately placed in sterile plastic bags, sealed, and transported to the laboratory on ice. The collected samples were subsequently divided into three parts. The first part was incubated to determine anammox and denitrification activities immediately, the second part was stored at $4^{\circ} \mathrm{C}$ for subsequent analysis of physicochemical properties, and the third part was stored at $-80^{\circ} \mathrm{C}$ for DNA extraction and molecular analyses.

\section{Analyses of Red Soil Physicochemical Properties}

$\mathrm{pH}$ of red soil was measured at a soil/Milli-Q water ratio of 1:2.5 with a $\mathrm{pH}$ analyzer (Mettler Toledo S220, Switzerland). Dissolved inorganic nitrogen $\left(\mathrm{NH}_{4}^{+}, \mathrm{NO}_{2}^{-}\right.$, and $\left.\mathrm{NO}_{3}^{-}\right)$was extracted from the soil using $2 \mathrm{~mol} / \mathrm{L} \mathrm{KCl}$ at a liquid to solid ratio of 100 . The extraction process was as follows. Freeze-dried and sieved $100 \mathrm{mg}$ of a sediment sample was placed in a polyethylene centrifuge tube, and a $2 \mathrm{~mol} / \mathrm{L} \mathrm{KCl}$ solution was added to it. It was agitated on a rotary shaker for $8 \mathrm{~h}$. After that, the sediment was centrifuged for $10 \mathrm{~min}$ at $3500 \mathrm{rpm}$, and the supernatant was used to measure the dissolved inorganic nitrogen concentration. Concentrations of $\mathrm{NH}_{4}^{+}, \mathrm{NO}_{2}^{-}$, and $\mathrm{NO}_{3}^{-}$in the supernatants were determined by spectrometric detection methods described by Wu et al. (2016) and Guan et al. (2017). Total nitrogen (TN), organic carbon (\%), and the $\mathrm{C}: \mathrm{N}$ ratio in each sample were analyzed on an elemental analyzer (IsoPrime 100, Elemental, Germany) after leaching with $0.1 \mathrm{M} \mathrm{HCl}$ to remove sedimentary carbonate.

\section{Measurement of Potential Anammox and Denitrification Rates}

The potential rates of anammox and denitrification in the red soils were measured as described by Risgaard-Petersen et al. (2003) and Hou et al. (2012) with a slight modification, and their relative contributions to $\mathrm{N}_{2}$ production were calculated based on these rates. Briefly, $30 \mathrm{~g}$ of field moist soils was transferred to a $250 \mathrm{~mL}$ glass bottle with helium-purged water 


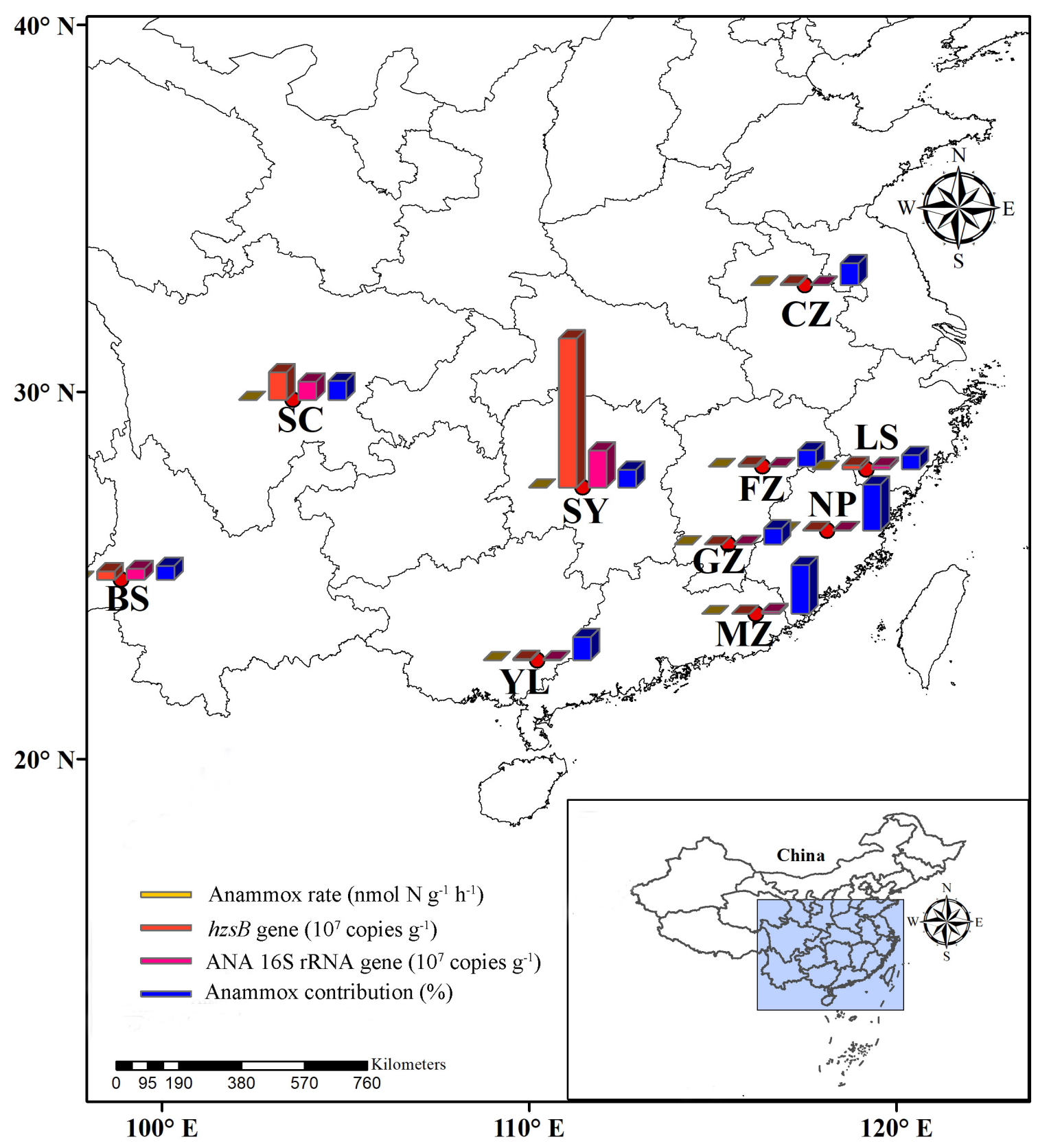

FIGURE 1 | Study area. This figure shows the location of the Southern China and sampling sites of red soils.

at a volume ratio of 1:5. The mixture was purged with helium for $30 \mathrm{~min}$. The resulting soil slurries were transferred into gas-tight $12.5 \mathrm{~mL}$ helium-flushed glass vials (Labco Exetainters, United Kingdom) under helium. Next, these slurries were incubated for approximately $24 \mathrm{~h}$ to remove residual $\mathrm{NO}_{\mathrm{x}}^{-}$ and dissolved oxygen at in situ sampling temperature. The ${ }^{15} \mathrm{~N}$ atom\% (Fn, represents the fraction of ${ }^{15} \mathrm{~N}$ in total $\mathrm{NO}_{3}^{-}$) was calculated by taking into account ${ }^{15} \mathrm{~N}$ atom\% of stock solutions and any residual ambient ${ }^{14} \mathrm{NO}_{3}^{-}$as determined by difference, ranging from 0.80 to 0.98 . After pre-incubation, these vials with slurries were divided into three groups, which were spiked through the septum with helium-purged stock solutions of (1) ${ }^{15} \mathrm{NH}_{4}^{+}\left({ }^{15} \mathrm{~N}\right.$ at $\left.99.6 \%\right)$, (2) ${ }^{15} \mathrm{NH}_{4}^{+}+{ }^{14} \mathrm{NO}_{3}^{-}$, and (3) ${ }^{15} \mathrm{NO}_{3}^{-}\left({ }^{15} \mathrm{~N}\right.$ at $\left.99 \%\right)$. The final concentration of ${ }^{15} \mathrm{~N}$ in each vial was $\sim 100 \mu \mathrm{M}$. Samples for dissolved gas analysis were preserved with $200 \mu \mathrm{L}$ of a $50 \% \mathrm{ZnCl}_{2}$ solution and analyzed within $8 \mathrm{~h}$. Membrane inlet mass spectrometry (MIMS, Hiden) was employed to measure the concentrations of ${ }^{29} \mathrm{~N}_{2}$ and ${ }^{30} \mathrm{~N}_{2}$ produced during the incubation period. Finally, the developed methods were used to calculate the rates of both anammox and denitrification and their potential contribution to $\mathrm{N}_{2}$ production. 
TABLE 1 | Characteristics of the collected red soils in Southern China.

\begin{tabular}{|c|c|c|c|c|c|c|c|c|c|c|}
\hline Province & City & Samples & Position & $\mathrm{pH}$ & $\mathrm{NH}_{4}^{+}\left(\mathrm{mg} \mathrm{kg}^{-1}\right)$ & $\mathrm{NO}_{3}^{-}\left(\mathrm{mg} \mathrm{kg}^{-1}\right)$ & $\mathrm{NO}_{2}^{-}\left(\mathrm{mg} \mathrm{kg}^{-1}\right)$ & $\mathrm{TN}\left(\mathrm{mg} \mathrm{kg}^{-1}\right)$ & C (\%) & $\mathrm{C}: \mathrm{N}$ \\
\hline Yunnan & Baoshan & $\mathrm{BS}$ & $98^{\circ} 52^{\prime} \mathrm{E}, 24^{\circ} 53^{\prime} \mathrm{N}$ & 6.02 & 69.12 & 49.17 & 4.59 & 570 & 0.433 & 7.60 \\
\hline Anhui & Chuzhou & $\mathrm{CZ}$ & $117^{\circ} 30^{\prime} \mathrm{E}, 32^{\circ} 54^{\prime} \mathrm{N}$ & 5.78 & 29.72 & 300.61 & 4.59 & 120 & 0.064 & 5.33 \\
\hline Jiangxi & Fuzhou & $\mathrm{FZ}$ & $116^{\circ} 20^{\prime} \mathrm{E}, 27^{\circ} 57^{\prime} \mathrm{N}$ & 5.18 & 45.11 & 14.27 & 4.77 & 180 & 0.116 & 6.44 \\
\hline Jiangxi & Ganzhou & $\mathrm{GZ}$ & $115^{\circ} 25^{\prime} \mathrm{E}, 25^{\circ} 50^{\prime} \mathrm{N}$ & 4.40 & 41.23 & 14.27 & 3.69 & 200 & 0.201 & 10.05 \\
\hline Zhejiang & Lishui & LS & $119^{\circ} 10^{\prime} \mathrm{E}, 27^{\circ} 53^{\prime} \mathrm{N}$ & 4.55 & 42.26 & 63.56 & 3.33 & 130 & 0.178 & 13.69 \\
\hline Guangdong & Meizhou & $M Z$ & $116^{\circ} 10^{\prime} \mathrm{E}, 23^{\circ} 57^{\prime} \mathrm{N}$ & 4.82 & 39.79 & 5.49 & 5.40 & 70 & 0.062 & 8.86 \\
\hline Fujian & Nanping & NP & $118^{\circ} 45^{\prime} \mathrm{E}, 27^{\circ} 32^{\prime} \mathrm{N}$ & 5.08 & 38.80 & 28.55 & 2.25 & 120 & 0.115 & 9.58 \\
\hline Sichuan & Leshan & SC & $103^{\circ} 32^{\prime} \mathrm{E}, 29^{\circ} 47^{\prime} \mathrm{N}$ & 5.06 & 27.25 & 3.29 & 2.25 & 70 & 0.056 & 8.00 \\
\hline Hunan & Shaoyang & SY & $111^{\circ} 27^{\prime} \mathrm{E}, 27^{\circ} 23^{\prime} \mathrm{N}$ & 4.65 & 45.18 & 25.50 & 5.22 & 570 & 0.366 & 6.42 \\
\hline Guangxi & Yulin & $\mathrm{YL}$ & $110^{\circ} 12^{\prime} \mathrm{E}, 22^{\circ} 41^{\prime} \mathrm{N}$ & 4.56 & 65.25 & 10.37 & 2.70 & 170 & 0.238 & 14.00 \\
\hline
\end{tabular}

\section{DNA Extraction and PCR Amplification}

Approximately $0.3 \mathrm{~g}$ of red soil was used for genomic DNA extraction using the PowerSoil DNA Isolation Kit (Mobio, United States). DNA quality and quantity were checked on a NanoDrop spectrophotometer (NanoDrop Technologies, Wilmington, DE, United States). Anammox bacteria were targeted by the barcoding primers A438f and A684r. The forward primer of A438f was attached to a unique 8 bp barcode sequence. More details of the primers and PCR amplification program are given in Supplementary Table 1. The amplified products were verified by electrophoresis in a $1.0 \%$ agarose gel and then purified using a MiniBEST agarose gel DNA extraction kit (TaKaRa, Beijing, China) before high-throughput sequencing.

\section{High-Throughput Sequencing and Analysis}

Data analysis of high-throughput raw sequences was conducted in the Mothur software v.1.35.1 following the standard protocol ${ }^{1}$ (Schloss et al., 2009). The obtained reads were processed by removing tags and primers before the sequence read numbers per sample were grouped together. The qualitytrimmed sequences were aligned to the newly developed anammox $16 \mathrm{~S}$ rRNA gene databases. The chimeric sequences were identified and removed by the Chimera-uchime. Highquality anammox bacterial sequences were used to generate a distance matrix and cluster with the average neighbor algorithm. Representative sequences for each operational taxonomic unit (OTU) as defined by $97 \%$ sequence identity were obtained for further diversity analyses (Zhao et al., 2013). Phylogenetic analysis of the representative anammox bacterial $16 \mathrm{~S}$ rRNA gene sequences from each OTU was conducted with the MEGA 7.0 software. A heat map was constructed based on the abundance of top 30 OTUs. Principal coordinates analysis (PCoA) was conducted by Normalized weighted Unifrac (Lozupone et al., 2006). Canonical correspondence analysis (CCA) was performed using the CANOCO 5.0 software. The plots in this study were created in SigmaPlot (version 12.5).

\footnotetext{
${ }^{1}$ http://www.mothur.org
}

\section{qPCR Analysis of $h z s B$ and 16S rRNA Genes of Anammox Bacteria}

The abundance of the $h z s B$ gene and 16S rRNA gene of anammox bacteria was determined in triplicate on a Bio-Rad iQ5 thermal cycler (Bio-Rad Laboratories) with primer sets HSBeta396FHSBeta742R and A438f-A684r, respectively. More details of qPCR assays are given in Supplementary Table 1. Plasmids carrying the targeted gene fragments were extracted from Escherichia coli DH5 $\alpha$ hosts using a Plasmid Mini Preparation Kit (TaKaRa, Beijing, China). Standard curves were built using 10fold serial dilution of the plasmid with target anammox bacterial genes: $h z s B$ and 16S rRNA gene. Specificity of the amplified products was checked by examination of a single melting peak and the presence of a unique band of the expected size in a $2 \%$ agarose gel stained with ethidium bromide. The results with efficiency and correlation coefficient above $90 \%$ and 0.97 were employed in this study.

\section{Statistical Analysis}

The relations among the activity, abundance of anammox bacteria, and different environmental factors were examined by Pearson correlation analyses using Statistical Analysis System (SAS 9.4).

\section{Nucleotide Sequence Accession Numbers}

The raw Illumina reads of $16 \mathrm{~S}$ rRNA gene sequences of anammox bacteria were deposited in the NCBI short-read archive under the Accession No. SRP140525.

\section{RESULTS}

\section{Physicochemical Properties of Red Soils}

The concentrations of $\mathrm{NH}_{4}^{+}, \mathrm{NO}_{3}^{-}, \mathrm{NO}_{2}^{-}$, $\mathrm{TN}$, and $\mathrm{C}(\%)$ and the ratio C:N of red soils from nine provinces of Southern China are listed in Table 1. The $\mathrm{pH}$ values of all collected red soil samples were relatively low, ranging from 4.40 to 6.02 . High concentrations of $\mathrm{NH}_{4}^{+}$were characteristic of all red soils, ranging from 27.25 to $69.12 \mathrm{mg} \mathrm{kg}^{-1}$. $\mathrm{NO}_{3}^{-}$concentrations (ranging from 3.29 to $300.61 \mathrm{mg} \mathrm{kg}^{-1}$ ) were lower than those of $\mathrm{NH}_{4}^{+}$ 
but peaked in sample CZ (300.61 $\left.\mathrm{mg} \mathrm{kg}^{-1}\right)$ in Anhui Province. The concentrations of $\mathrm{NO}_{2}^{-}$were relatively low and ranged from 2.25 to $5.40 \mathrm{mg} \mathrm{kg}^{-1}$. The soil TN and C\% contents were lower than those in other agricultural soils, which varied from 70 to $570 \mathrm{mg} \mathrm{kg}^{-1}$ and 0.056 to $0.433 \%$, respectively. Such differences may be the result of less application of fertilization in natural red soils. Most of the samples had a low C:N ratio (ranging from 5.33 to 10.05). Nonetheless, samples LS and YL showed relatively higher C:N ratios (13.69 and 14.00). The physicochemical properties of red soils in this study were in the same range as other reported values for red soils (Wilson et al., 2004).

\section{The Potential Rates of Anammox and Contribution to $\mathbf{N}_{2}$ Production}

The potential anammox and denitrification rates were determined in red soils based on the incubation of ${ }^{15} \mathrm{NO}_{3}^{-}$. The potential anammox rates ranged from $0.01 \pm 0.00$ to $0.59 \pm 0.07$ nmol $\mathrm{N} \mathrm{g}^{-1}$ dry red soil $\mathrm{h}^{-1}$, while denitrification rates ranged from $0.01 \pm 0.01$ to $1.63 \pm 0.19 \mathrm{nmol} \mathrm{N} \mathrm{g}^{-1}$ dry red soil $\mathrm{h}^{-1}$ (Figure 2 and Supplementary Table 2). Denitrification rates were higher than anammox rates, suggesting that denitrification dominated the total nitrogen loss in red soils. The highest anammox and denitrification rates were both observed in $\mathrm{CZ}$ in Hunan province. The red soil collected in SC, YL, MZ, and GZ showed relatively lower potential anammox rates. The relative contribution of anammox to $\mathrm{N}_{2}$ production varied from 16.67 to $53.27 \%$.

\section{Abundance of Anammox Bacteria}

The $h z s B$ gene and anammox $16 \mathrm{~S}$ rRNA gene were used to estimate the abundance of anammox bacteria in red soils by the qPCR method. The abundance of anammox bacteria ranged

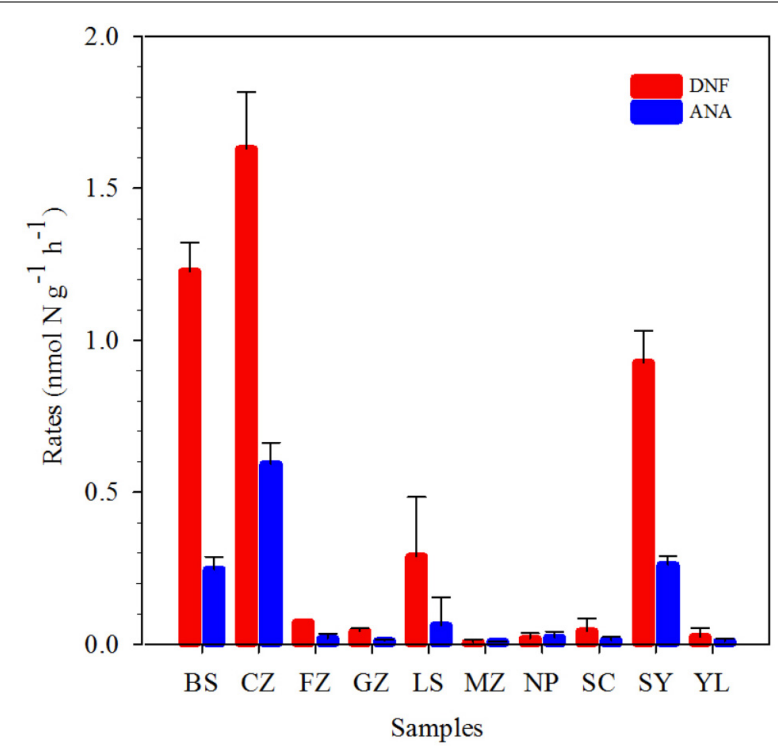

FIGURE 2 | Denitrification (DNF, red) and anammox rates (ANA, blue) in the red soils. Vertical bars denote standard error of triplicate samples.

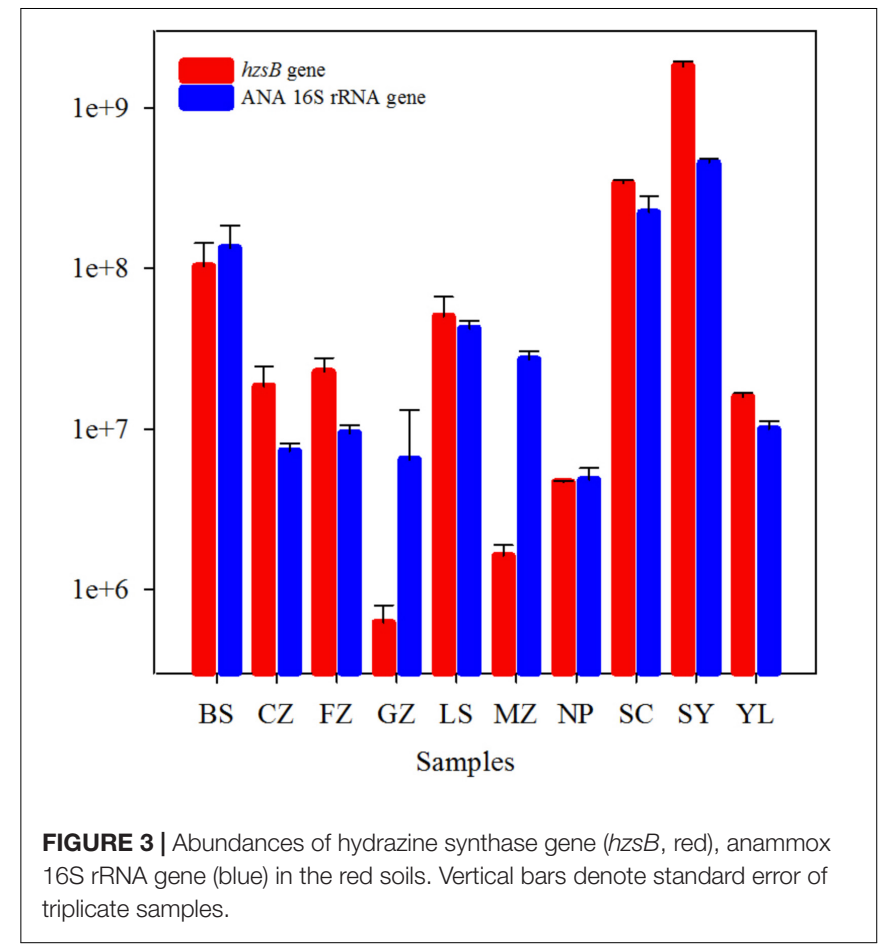

from $6.20 \times 10^{5}$ to $1.81 \times 10^{9}\left(h z s B\right.$ gene) and $4.81 \times 10^{6}$ to $4.54 \times 10^{8}$ (anammox $16 \mathrm{~S}$ rRNA gene) copies per gram of dry weight (Figure 3). The highest abundance of anammox bacteria was observed in sample CZ, while other samples had values between $10^{5}$ and $10^{8}$ copies/g. $h z s B$ was slightly more abundant than the 16S rRNA gene of anammox bacteria (the hzsB/anammox 16S rRNA gene ratio was 2.18 ) in red soils. The presence of anammox bacteria was ascertained in the current study by the positive correlation between $h z s B$ and ANA 16S rRNA gene $(r=0.818, P<0.001, n=10)$.

\section{Community Composition and Phylogenetic Analysis of Anammox Bacteria}

A total of 0.14 million of anammox raw sequences (15000 sequence reads per sample except NP, which contained only 7222 sequences reads) were subjected to denoising and trimming of sequences. After quality controls, $\sim 12000$ reads per sample was filtered as high-quality reads for further analysis (Table 2).

Based on the 0.03 distance level, 138 OTUs (77 \pm 7 OTUs per sample, $n=10$ ) of the anammox $16 \mathrm{~S}$ RNA gene were obtained (Table 2). The highest number of OTUs was seen in sample GZ (84 OTUs). The Chaol and ACE richness estimators of anammox bacteria ranged from 89.169 to 107.521 and 107.027 to 164.916, respectively. Higher richness of anammox bacteria was found in sample BS. The Shannon index showed that the highest diversity of anammox bacteria was detected in sample NP (0.624), whereas sample MZ (0.263) had the lowest diversity among red soils. The evenness of anammox bacteria was low in red soil and ranged from 0.060 to 0.150 . Good's coverage values varied from 0.995 to 0.996 , suggesting that the libraries were adequately 
TABLE 2 | Estimates of sedimentary 16S rRNA gene sequence richness and diversity in different red soils.

\begin{tabular}{|c|c|c|c|c|c|c|c|}
\hline Samples & High-quality reads & OTUs $^{a}$ & Chao $^{a}$ & $\mathrm{ACE}^{\mathrm{a}}$ & Shannon ${ }^{a}$ & Evenness $^{b}$ & Coverage \\
\hline BS & 12450 & 74 & 89.169 & 107.027 & 0.334 & 0.077 & 0.996 \\
\hline $\mathrm{CZ}$ & 11823 & 77 & 89.366 & 130.129 & 0.542 & 0.125 & 0.995 \\
\hline$F Z$ & 12425 & 78 & 93.469 & 135.885 & 0.444 & 0.102 & 0.995 \\
\hline GZ & 12280 & 84 & 105.999 & 164.916 & 0.530 & 0.120 & 0.995 \\
\hline LS & 12501 & 82 & 96.499 & 140.765 & 0.365 & 0.083 & 0.995 \\
\hline$M Z$ & 12461 & 80 & 95.796 & 138.615 & 0.263 & 0.060 & 0.995 \\
\hline NP & 5824 & 64 & 97.833 & 132.182 & 0.624 & 0.150 & 0.995 \\
\hline SC & 12500 & 81 & 99.562 & 148.988 & 0.320 & 0.073 & 0.995 \\
\hline SY & 12349 & 75 & 91.721 & 126.715 & 0.361 & 0.084 & 0.996 \\
\hline YL & 12404 & 82 & 107.521 & 137.841 & 0.493 & 0.112 & 0.995 \\
\hline
\end{tabular}

${ }^{a}$ Richness and diversity were determined based on 0.03 distance.

${ }^{b}$ Evenness was calculated by dividing Shannon index by Ln (OTUs).

large. Rarefaction curves (Supplementary Figure 2) and a rankabundance curve (Supplementary Figure 3) for the anammox bacterial 16S rRNA gene at 97\% similarity showed that the highthroughput sequencing could supply enough bioinformation to investigate the community composition and diversity of anammox bacteria in the current study.

The community structure of anammox bacteria in red soil at the genus level is depicted in Figure 4. Gene sequences of anammox bacteria mainly belonged to Candidatus Brocadia (93.03\%), Candidatus Scalindua (0.09\%), Candidatus Anammoxoglobus (0.01\%), Candidatus Kuenenia (0.04\%) and unclassified (6.83\%). Candidatus Brocadia (93.03\%) was the dominant genus in acidic and natural red soils, whereas Candidatus Scalindua was more abundant in sample GZ. A heatmap (Figure 5A) and phylogenetic tree (Figure $5 \mathbf{B}$ and Supplementary Figure 4) of dominant anammox OTUs (top 30 OTUs, 99\% sequences were obtained) indicated that the top 30 OTUs were affiliated with only one cluster, which was closely related to Candidatus Brocadia fulgida. OTU 1 was the most abundant sequence in all the samples and had average relative abundance of 27.39 .

\section{Correlation Analysis of Anammox Potential Rates, Gene Abundances, and Red Soil Properties}

Pearson correlation analysis was used to illustrate the correlations among anammox potential rates, gene abundances, and red soil properties (Figure 6 and Supplementary Table 3). The results indicated that anammox rates positively correlated with $\mathrm{NO}_{3}^{-}$(coefficient $=0.889, P<0.001$ ). hzsB abundances positively correlated with TN (coefficient $=0.637, P<0.05$ ) and anammox 16S rRNA abundances (coefficient $=0.942, P<0.001$ ). Anammox 16S rRNA abundance also positively correlated with TN (coefficient $=0.652, P<0.05$ ). In addition, $\mathrm{C} \%$ positively correlated with $\mathrm{NH}_{4}^{+}$(coefficient $=0.779, P<0.001$ ) and TN (coefficient $=0.993, P<0.001$ ) in red soils. As revealed by $\mathrm{CCA}, \mathrm{pH}$ and $\mathrm{NO}_{3}^{-}$were found to be the main factors affecting the distribution of anammox bacteria in the red soils (Supplementary Figure 5).

\section{DISCUSSION}

Recently, increasing evidences showed that anammox bacteria play a significant role in nitrogen loss in agricultural soils, particularly paddy soils (Zhu et al., 2011; Wang and Gu, 2013; Wang et al., 2014; Nie et al., 2015; Yang et al., 2015). In the present study, we present the evidence of anammox process for the first time in 10 different acidic red soils of Southern China by combining the ${ }^{15} \mathrm{~N}$-labeling approach, qPCR analysis, and high-throughput sequencing. The potential anammox rates, ranging from $0.01 \pm 0.00$ to $0.59 \pm 0.07 \mathrm{nmol} \mathrm{N} \mathrm{g}^{-1}$ dry red soil $\mathrm{h}^{-1}$ (Figure 2 and Supplementary Table 2), were examined in all the selected red soils, revealing the same range as that found in agricultural soils (Long et al., 2013; Nie et al., 2015) and forest soils (Xi et al., 2016), but lower than other values reported for fertilized paddy soils and agricultural fields (Zhu et al., 2011; Yang et al., 2015; Shen et al., 2016, 2017). Red soils in China were found to be characterized by low $\mathrm{pH}, \mathrm{TN}$, and organic carbon, in contrast to other fertilized agricultural soils (Table 1). The physicochemical properties of red soils were found to be the most important factors influencing the potential anammox and denitrification rates, especially soil organic carbon and TN. Soil organic carbon can enhance microbial activities and improve physical and chemical conditions of the soil (Pulleman et al., 2000; Zhang et al., 2009). These results indicated that the characteristics of red soil may influence the activity of anammox bacteria. Other studies also showed that flooding and fertilization conditions made the paddy soils a suitable habitat for anammox bacteria (Shen et al., 2017). Zhu et al. (2011) found many microniches were existed in a paddy soil; thus, it could support the various ecophysiologies of the different anammox genera and facilitate the anammox activity. In addition, it should be noticed that slurry incubations may underestimate the in situ anammox activity due to the following reasons. Firstly, the incubation conditions at higher moisture may affect the microbial community, which results in underestimation of the denitrification and anammox rate. Finally, the incubation time of $24 \mathrm{~h}$ may not be enough to eliminate the initial ${ }^{14} \mathrm{NO}_{3}^{-}$in sample CZ (Fn: 0.80) and LS (Fn: 0.87), which may underestimate the potential rates. Different potential rates of 


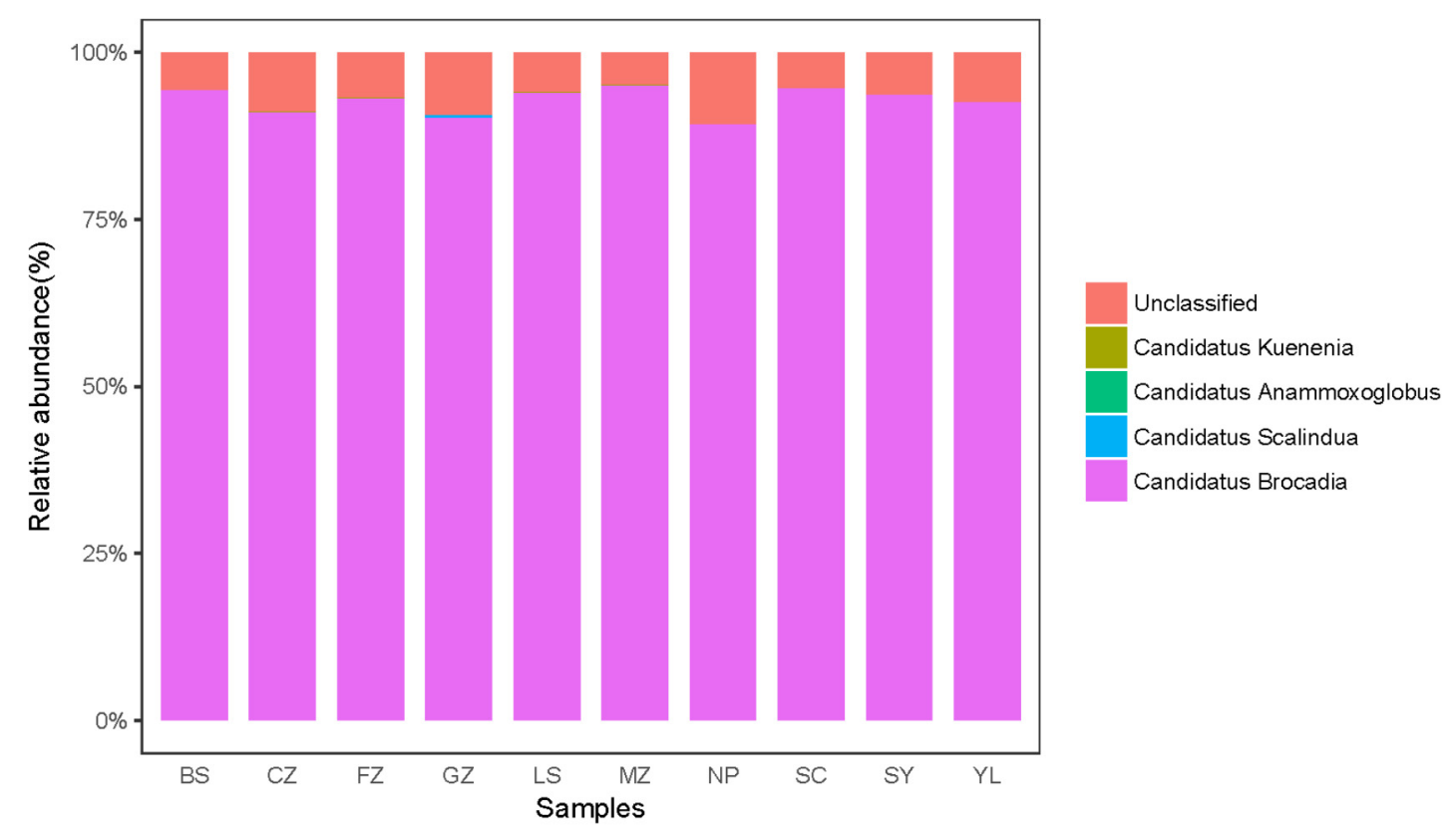

FIGURE 4 | Taxonomic classifications of anammox 16S rRNA gene reads retrieved from the red soils at genus level.

A

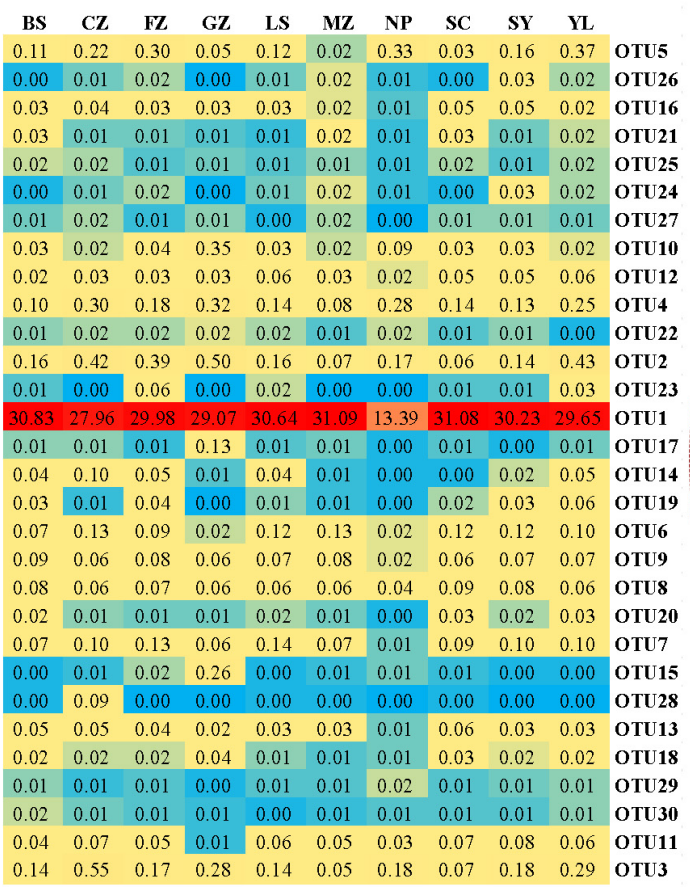

B

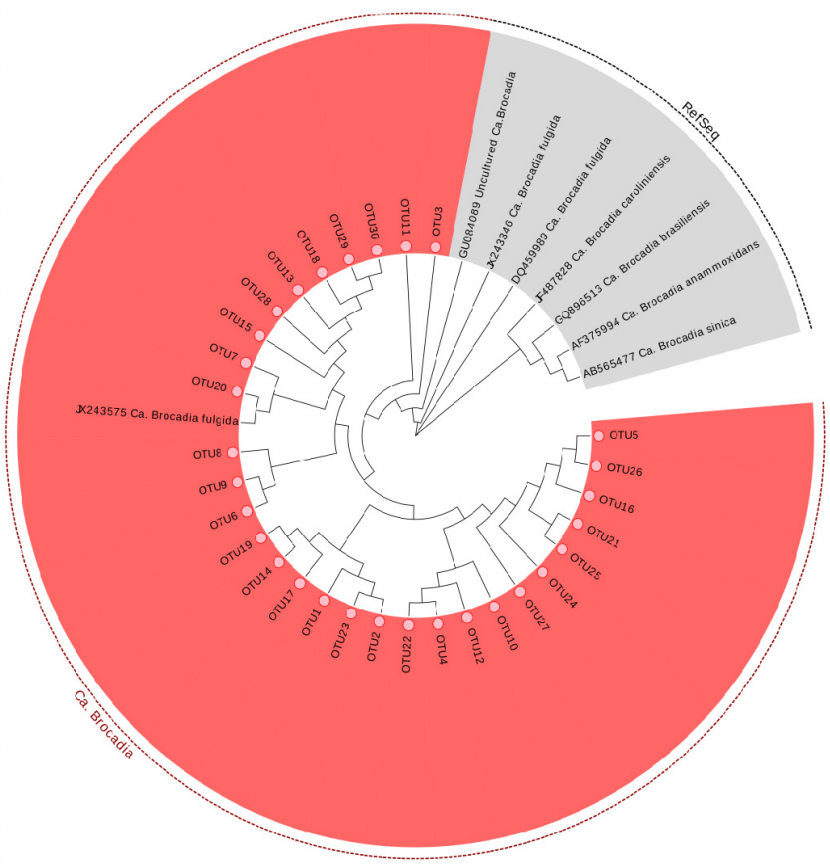
FIGURE 5 | Microbial characteristics of the anammox $16 \mathrm{~S}$ rRNA gene in the red soils. (A) The heat map of the most abundant anammox OTUs (Top 30 OTUs, $97 \%$
cutoff). (B) Neighbor-joining phylogenetic tree of the dominant (Top 30 OTUs) anammox OTUs and the reference sequences from GenBank. Bootstrap values were 1000 replicates.

anammox were observed in 10 samples from nine provinces of Southern China (Figure 2). Cultivation history, land use patterns, and a cropping system are the important factors influencing

the physicochemical properties of red soil in different provinces (Shen et al., 2013). Anammox contributed 16.67 to $53.27 \%$ to red soil $\mathrm{N}_{2}$ production (Figure 2 and Supplementary Table 2), 


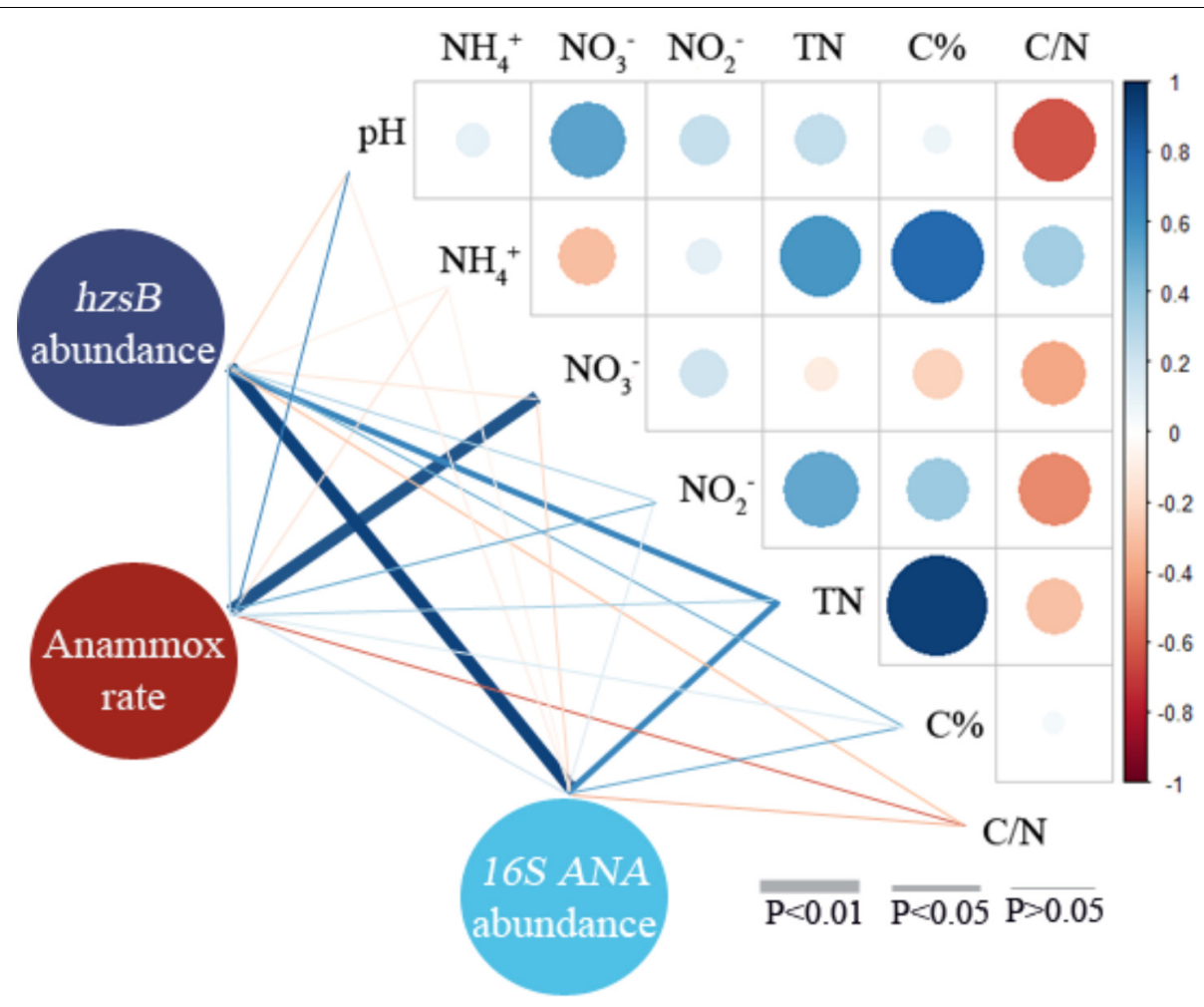

FIGURE 6 | Pearson correlation analyses of anammox rate, $h z s B$ abundance, anammox $16 \mathrm{~S}$ rRNA gene abundance, and environmental characteristics of red soils (including $\mathrm{pH}, \mathrm{NH}_{4}^{+}, \mathrm{NO}_{3}^{-}, \mathrm{NO}_{2}^{-}, \mathrm{TN}, \mathrm{C} \%$, and $\mathrm{C} / \mathrm{N}$ ). Blue and red denote positive and negative correlations, respectively.

suggesting that anammox should be recognized as a significant $\mathrm{N}$ sink in red soil. On the base of the soil density, the average potential anammox rate, and red soil area in southern China, $\mathrm{N}$ loss attributed to anammox was estimated to reach $\sim 2.33 \mathrm{Tg}$ $\mathrm{N}$ per year. This result was comparable to previously reported values (2.50 $\mathrm{Tg} \mathrm{N}$ per year) in paddy soil in Southern China (Yang et al., 2015), demonstrating the importance of anammox in red soil ecosystems. Pearson correlation analyses showed that the potential anammox rates positively correlated with $\mathrm{NO}_{3}^{-}$ (coefficient $=0.889, P<0.001$ ) (Figure 6 and Supplementary Table 3). Previous study on freshwater sediments also suggested that $\mathrm{NO}_{3}^{-}$is a factor controlling anammox rates (Yoshinaga et al., 2011). Anammox bacteria are favored in environments where $\mathrm{NO}_{3}^{-}$is available (Trimmer et al., 2003; Engström et al., 2005; Yang et al., 2015).

The abundance of anammox bacteria ranged from $6.20 \times 10^{5}$ to $1.81 \times 10^{9} h z s B$ copies/g and $4.81 \times 10^{6}$ to $4.54 \times 10^{8}$ (anammox bacterial 16S rRNA gene), which fall within the ranges reported in Pearl River Estuary $\left(1.4-20 \times 10^{8} \mathrm{hzsB}\right.$ copies/g; Wang et al., 2012), Yangtze Estuary $\left(3.67-822 \times 10^{5} 16 \mathrm{~S}\right.$ rRNA copies/g; Zheng et al., 2016), and paddy soils $\left(0.7-1.4 \times 10^{7} \mathrm{hzs}\right.$ copies/g; Nie et al., 2015). Anammox bacterial abundances in red soils were confirmed by means of the anammox $h z s B$ gene and $16 \mathrm{~S}$ rRNA gene (Figure 3), and abundances of these two target genes correlated $(r=0.818, P<0.001, n=10)$. In this study, TN concentration was identified as an important factor influencing the anammox bacterial abundance in selected red soils (Figure 6 and Supplementary Table 3). It can be speculated that higher TN concentration may provide an environment favorable for the distribution and growth of anammox bacteria (Shen et al., 2016). In line with other studies (Metz et al., 2003; Etchebehere and Tiedje, 2005; Yang et al., 2017), a positive correlation between anammox activity and abundance ( $h z s B$ or $16 \mathrm{~S}$ rRNA gene) was not observed. These results indicated that anammox rates are limited not by the presence of the population capable of anammox but by the availability of $\mathrm{NO}_{3}^{-}$or $\mathrm{NH}_{4}^{+}$ as substrate. If anammox bacterial abundance correlated with their activities, it suggested that anammox bacterial abundance has a potential to predict anammox activity (Dale et al., 2009). Concentrations of $\mathrm{NO}_{3}^{-}$and/or $\mathrm{NH}_{4}^{+}$have been reported to significantly affect the anammox rate (Shen et al., 2013). Lisa et al. (2015) found that physiological nature of an organism and the environmental conditions of the system are the two important factors influencing whether the genetic potential may or may not predict the potential for that process. Furthermore, the presence of anammox bacteria detected by gene amplification is not an indication of their level of activity as would be indicated by active community (cDNA) qualification.

Some studies have reported that Candidatus Scalindua is the exclusive anammox genus in marine ecosystems (Schmid et al., 2007; Hong et al., 2011a,b). In this study, Candidatus Brocadia dominated the anammox community in acidic red soils. In total, $93.03 \%$ sequence reads of anammox bacteria were related to Candidatus Brocadia (Figure 4) and the dominant 
OTUs (TOP 30) were all affiliated with Candidatus Brocadia fulgida (Figure 5). Candidatus Brocadia was reported to be the most common anammox genus in terrestrial ecosystems, including paddy soils (50\%, Yang et al., 2015) and Chinese agricultural soils (75\%, Shen et al., 2013). Some studies showed that Candidatus Brocadia possesses diverse metabolic pathways (Gori et al., 2011) and better adaptability to terrestrial soils than do other anammox genera (Shen et al., 2013). Kartal et al. (2008) found that Candidatus Brocadia fulgida can use shortchain organic acids as alternative electron donors to reduce $\mathrm{NO}_{2}^{-}$ to $\mathrm{N}_{2}$. Candidatus Brocadia belongs to the r-strategists, making it suitable for the higher substrate concentration, and it will outcompete other anammox genera (Strous, 1999; Gao et al., 2018). CCA suggests that $\mathrm{pH}$ and $\mathrm{NO}_{3}^{-}$were the main factors affecting the distribution of anammox bacteria in the red soils (Supplementary Figure 5). According to the composition of anammox bacteria communities of different samples (Table 2 and Figure 5A), higher Shannon (0.542) and evenness indexes (0.125) were detected in sample $\mathrm{CZ}$ with higher $\mathrm{pH}$ (5.78) and $\mathrm{NO}_{3}^{-}$values (300.61 $\mathrm{mg} \mathrm{kg}^{-1}$ ). This situation may lead to the higher diversity of anammox bacteria observed in samples with higher $\mathrm{pH}$ and $\mathrm{NO}_{3}^{-}$content. Here, the presence and activity of anammox bacteria were detected successfully in acidic red soils ( $\mathrm{pH}$ ranged from 4.40 to 6.02 ). The reported optimal $\mathrm{pH}$ range for Candidatus Brocadia fulgida is 7.2 to 8.3 (Oshiki et al., 2016). Our study extended the $\mathrm{pH}$ range in which anammox bacteria can survive and their activity can be detected. A special membrane probably present in the cell of anammox bacteria, so they can survive in acidic environments. Yang et al. (2015) also found that $\mathrm{pH}$ significantly correlates with the anammox bacterial composition in paddy soils. Additionally, $\mathrm{NO}_{3}^{-}$content had a significant contribution to anammox bacterial community structure, which may be attributed to an increased supply of $\mathrm{NO}_{2}^{-}$ via reduction of $\mathrm{NO}_{3}^{-}$. Similar results have also been observed in the sediments of the Dongjiang River (Sun et al., 2013) and Mai Po Nature Reserve (Li et al., 2011).

Thus, both the presence and activity of anammox bacteria were for the first time shown in 10 different acidic red soils from nine provinces in Southern China. These data expand the knowledge of the distribution and $\mathrm{N}$ loss contribution of anammox bacteria in acidic red soils. Our high-throughput sequencing analysis indicates that Candidatus Brocadia dominates the anammox bacterial community. Anammox

\section{REFERENCES}

Dale, O. R., Tobias, C. R., and Song, B. (2009). Biogeographical distribution of diverse anaerobic ammonium oxidizing (anammox) bacteria in cape fear river estuary. Environ. Microbiol. 11, 1194-1207. doi: 10.1111/j.1462-2920.2008. 01850.x

Dang, H., Zhou, H., Zhang, Z., Yu, Z., Hua, E., Liu, X., et al. (2013). Molecular detection of Candidatus scalindua pacifica and environmental responses of sediment anammox bacterial community in the bohai sea, China. PLoS One 8:e61330. doi: 10.1371/journal.pone.0061330

Engström, P., Dalsgaard, T., Hulth, S., and Aller, R. C. (2005). Anaerobic ammonium oxidation by nitrite (anammox): implications for $\mathrm{N}_{2}$ production in coastal marine sediments. Geochim. Cosmochim. Acta 69, 2057-2065. doi: 10.1016/j.gca.2004.09.032 contributed 16.67 to $53.27 \%$ to red soil $\mathrm{N}_{2}$ production, which was the vital $\mathrm{N}$ sink (2.33 Tg N per year) in red soils of Southern China. These results demonstrate the lower diversity but higher contribution of anammox bacteria to the removal of fixed $\mathrm{N}$ from acidic red soils.

\section{AUTHOR CONTRIBUTIONS}

JW, YH, XH, LJ, and XW performed the research. JW, YH, SC, GC, YL, TH, YHH, and XL analyzed the data. JW and $\mathrm{YH}$ wrote the paper. All co-authors substantially contributed to commenting and revising it and read and approved the final manuscript.

\section{FUNDING}

This work was financially supported by National Natural Science Foundation of China (Grant Nos. 41576123 and 31870100), National Key Basic Research Program of China (Grant No. 2015CB452902), Strategic Priority Research Program of the Chinese Academy of Sciences (Grant No. XDA11020202), Natural Science Foundation of Guangdong (Grant No. S2013020012823), Scientific Research Project of Guangzhou (Grant No. 201504010005), and Research Foundation for Talented Scholars of Guangzhou University (Grant No. GU2017001).

\section{ACKNOWLEDGMENTS}

We would like to thank Chunyu Zhao, Jiaqi Ye, Tongxin Li, and Yuwei Li for their kind help; Jinxing Wu, Mingshan Chen, and Lizhao Chen are gratefully acknowledged for their detailed and patient favor in red soil sampling.

\section{SUPPLEMENTARY MATERIAL}

The Supplementary Material for this article can be found online at: https://www.frontiersin.org/articles/10.3389/fmicb. 2018.02142/full\#supplementary-material

Erguder, T. H., Boon, N., Wittebolle, L., Marzorati, M., and Verstraete, W. (2009). Environmental factors shaping the ecological niches of ammonia-oxidizing archaea. FEMS Microbiol. Rev. 33, 855-869. doi: 10.1111/j.1574-6976.2009. 00179.x

Etchebehere, C., and Tiedje, J. (2005). Presence of two different active nirS nitrite reductase genes in a denitrifying Thauera sp. from a high-nitrate-removal-rate reactor. Appl. Environ. Microbiol. 71, 5642-5645. doi: 10.1128/AEM.71.9.56425645.2005

Gao, D., Wang, X., Liang, H., Wei, Q., Dou, Y., and Li, L. (2018). Anaerobic ammonia oxidizing bacteria: ecological distribution, metabolism, and microbial interactions. Front. Environ. Sci. Eng. 12:10. doi: 10.1007/s11783-0181035-x

Gleeson, D. B., Müller, C., Banerjee, S., Ma, W., Siciliano, S. D., and Murphy, D. V. (2010). Response of ammonia oxidizing archaea and bacteria to changing water 
filled pore space. Soil Biol. Biochem. 42, 1888-1891. doi: 10.1016/j.soilbio.2010. 06.020

Gori, F., Tringe, S. G., Kartal, B., Marchiori, E., Machiori, E., and Jetten, M. S. (2011). The metagenomic basis of anammox metabolism in Candidatus 'Brocadia fulgida'. Biochem. Soc. Trans. 39, 1799-1804. doi: 10.1042/ BST20110707

Guan, F., Hong, Y., Jiapeng, W. U., Wang, Y., Liying, B., Tang, B., et al. (2017). A fast sodium hypobromite oxidation method for the sequential determination of ammonia nitrogen in small volume. Ecol. Sci. 36, 42-48.

Gubryrangin, C., Hai, B., Quince, C., Engel, M., Thomson, B. C., James, P., et al. (2011). Niche specialization of terrestrial archaeal ammonia oxidizers. Proc. Natl. Acad. Sci. U.S.A. 108, 21206-21211. doi: 10.1073/pnas.11090 00108

Hong, Y. G., Li, M., Cao, H., and Gu, J. D. (2011a). Residence of Habitat-Specific anammox bacteria in the deep-sea subsurface sediments of the south China sea: analyses of marker gene abundance with physical chemical parameters. Microb. Ecol. 62, 36-47. doi: 10.1007/s00248-011-9849-0

Hong, Y. G., Yin, B., and Zheng, T. L. (2011b). Diversity and abundance of anammox bacterial community in the deep-ocean surface sediment from equatorial Pacific. Appl. Microbiol. Biotechnol. 89, 1233-1241. doi: 10.1007/ s00253-010-2925-4

Hou, L., Liu, M., Carini, S. A., and Gardner, W. S. (2012). Transformation and fate of nitrate near the sediment-water interface of copano bay. Cont. Shelf Res. 35, 86-94. doi: 10.1016/j.csr.2012.01.004

Jetten, M. S. M., Op den Camp, H. J. M., Kuenen, J. G., and Strous, M. (2010). “Description of the order brocadiales," in Bergey's Manual of Systematic Bacteriology, Vol. 4, eds N. R. Krieg, W. W. Ludwig and W. B. Whitman (Heidelberg: Springer), 596-603.

Kartal, B., Rattray, J., Niftrik, L. A. V., Vossenberg, J. V. D., Schmid, M. C., Webb, R. I., et al. (2007). Candidatus "Anammoxoglobus propionicus" a new propionate oxidizing species of anaerobic ammonium oxidizing bacteria. Syst. Appl. Microbiol. 30, 39-49. doi: 10.1016/j.syapm.2006.03.004

Kartal, B., Van Niftrik, L., Rattray, J., van de Vossenberg, J. L., Schmid, M. C., Sinninghe, D. J., et al. (2008). Candidatus 'Brocadia fulgida': an autofluorescent anaerobic ammonium oxidizing bacterium. FEMS Microbiol. Ecol. 63, 46-55. doi: 10.1111/j.1574-6941.2007.00408.x

Kuypers, M. M., Lavik, G., Woebken, D., Schmid, M., Fuchs, B. M., Amann, R., et al. (2005). Massive nitrogen loss from the benguela upwelling system through anaerobic ammonium oxidation. Proc. Natl. Acad. Sci. U.S.A. 102, 6478-6483. doi: 10.1073/pnas.0502088102

Li, M., Cao, H., Hong, Y. G., and Gu, J. D. (2011). Seasonal dynamics of anammox bacteria in estuarial sediment of the mai po nature reserve revealed by analyzing the 16S rRNA and hydrazine oxidoreductase (hzo) genes. Microbes Environ. 26, 15-22. doi: 10.1264/jsme2.ME10131

Lisa, J. A., Song, B., Tobias, C. R., and Hines, D. E. (2015). Genetic and biogeochemical investigation of sedimentary nitrogen cycling communities responding to tidal and seasonal dynamics in cape fear river estuary. Estuar. Coastal Shelf Sci. 167, A313-A323. doi: 10.1016/j.ecss.2015.09.008

Liu, H., Wu, X., Wang, Q., Wang, S., Liu, D., and Liu, G. (2017). Responses of soil ammonia oxidation and ammonia-oxidizing communities to land-use conversion and fertilization in an acidic red soil of southern China. Eur. J. Soil Biol. 80, 110-120. doi: 10.1016/j.ejsobi.2017.05.005

Long, A., Heitman, J., Tobias, C., Philips, R., and Song, B. (2013). Co-occurring anammox, denitrification, and codenitrification in agricultural soils. Appl. Environ. Microbiol. 79, 168-176. doi: 10.1128/AEM.02520-12

Lozupone, C., Hamady, M., and Knight, R. (2006). UniFrac-an online tool for comparing microbial community diversity in a phylogenetic context. BMC Bioinformatics 7:371. doi: 10.1186/1471-2105-7-371

Metz, S., Beisker, W., Hartmann, A., and Schloter, M. (2003). Detection methods for the expression of the dissimilatory copper-containing nitrite reductase gene (DnirK) in environmental samples. J. Microbiol. Methods 55, 41-50. doi: 10.1016/S0167-7012(03)00089-7

Mulder, A., van de Graaf, A. A., Robertson, L. A., and Kuenen, J. G. (1995). Anaerobic ammonium oxidation discovered in a denitrifying fluidized bed reactor. FEMS Microbiol. Ecol. 16, 177-184. doi: 10.1111/j.1574-6941.1995. tb00281.x

Nicol, G. W., Leininger, S., Schleper, C., and Prosser, J. I. (2008). The influence of soil $\mathrm{pH}$ on the diversity, abundance and transcriptional activity of ammonia oxidizing archaea and bacteria. Environ. Microbiol. 10, 2966-2978. doi: 10.1111/ j.1462-2920.2008.01701.x

Nie, S., Li, H., Yang, X., Zhang, Z., Weng, B., Huang, F., et al. (2015). Nitrogen loss by anaerobic oxidation of ammonium in rice rhizosphere. ISME J. 9, 2059-2067. doi: 10.1038 /ismej.2015.25

Oshiki, M., Satoh, H., and Okabe, S. (2016). Ecology and physiology of anaerobic ammonium oxidizing bacteria. Environ. Microbiol. 18, 2784-2796. doi: 10.1111/ 1462-2920.13134

Pulleman, M. M., Bouma, J., Essen, E. A. V., and Meijles, E. W. (2000). Soil organic matter content as a function of different land use history. Soil Sci. Soc. Am. J. 64, 689-693. doi: 10.2136/sssaj2000.642689x

Quan, Z. X., Rhee, S. K., Zuo, J. E., Yang, Y., Bae, J. W., Park, J. R., et al. (2008). Diversity of ammonium-oxidizing bacteria in a granular sludge anaerobic ammonium-oxidizing (anammox) reactor. Environ. Microbiol. 10, 3130-3139. doi: 10.1111/j.1462-2920.2008.01642.x

Risgaard-Petersen, N., Nielsen, L. P., Rysgaard, S., Dalsgaard, T., and Meyer, R. L. (2003). Application of the isotope pairing technique in sediments where anammox and denitrification coexist. Limnol. Oceanogr. Methods 1, 63-73. doi: 10.4319/lom.2003.1.63

Schloss, P. D., Westcott, S. L., Ryabin, T., Hall, J. R., Hartmann, M., Hollister, E. B., et al. (2009). Introducing mothur: open-source, platform-independent, community-supported software for describing and comparing microbial communities. Appl. Environ. Microbiol. 75, 7537-7541. doi: 10.1128/AEM. 01541-09

Schmid, M., Twachtmann, U., Klein, M., Strous, M., Juretschko, S., Jetten, M., et al. (2000). Molecular evidence for genus level diversity of bacteria capable of catalyzing anaerobic ammonium oxidation. Syst. Appl. Microbiol. 23, 93-106. doi: 10.1016/S0723-2020(00)80050-8

Schmid, M., Walsh, K., Webb, R., Rijpstra, W. I., van de Pas-Schoonen, K., Verbruggen, M. J., et al. (2003). Candidatus "Scalindua brodae", sp. nov., Candidatus "Scalindua wagneri", sp. nov., two new species of anaerobic ammonium oxidizing bacteria. Syst. Appl. Microbiol. 26, 529-538. doi: 10.1078/ 072320203770865837

Schmid, M. C., Risgaardpetersen, N., van de Vossenberg, J., Kuypers, M. M., Lavik, G., Petersen, J., et al. (2007). Anaerobic ammonium-oxidizing bacteria in marine environments: widespread occurrence but low diversity. Environ. Microbiol. 9, 1476-1484. doi: 10.1111/j.1462-2920.2007.01266.x

Shan, J., Yang, P., Shang, X., Rahman, M. M., and Yan, X. (2018). Anaerobic ammonium oxidation and denitrification in a paddy soil as affected by temperature, pH, organic carbon, and substrates. Biol. Fertil. Soils 54, 341-348. doi: $10.1007 / \mathrm{s} 00374-018-1263-\mathrm{z}$

Shan, J., Zhao, X., Sheng, R., Xia, Y., Ti, C., Quan, X., et al. (2016). Dissimilatory nitrate reduction processes in typical chinese paddy soils: rates, relative contributions, and influencing factors. Environ. Sci. Technol. 50, 9972-9980. doi: 10.1021/acs.est.6b01765

Shen, L., Wu, H., Liu, X., and Li, J. (2017). Vertical distribution and activity of anaerobic ammonium-oxidising bacteria in a vegetable field. Geoderma 288, 56-63. doi: 10.1016/j.geoderma.2016.11.007

Shen, L., Zheng, P., and Ma, S. (2016). Nitrogen loss through anaerobic ammonium oxidation in agricultural drainage ditches. Biol. Fertil. Soils 52, 127-136. doi: 10.1007/s00374-015-1058-4

Shen, L. D., Liu, S., Lou, L. P., Liu, W. P., Xu, X. Y., Zheng, P., et al. (2013). Broad distribution of diverse anaerobic ammonium-oxidizing bacteria in chinese agricultural soils. Appl. Environ. Microbiol. 79, 6167-6172. doi: 10.1128/AEM. 00884- 13

Strous, M. (1999). Key physiology of anaerobic ammonium oxidation. Appl. Environ. Microbiol. 65, 3248-3250.

Strous, M., Fuerst, J. A., Kramer, E. H., Logemann, S., Muyzer, G., van de Pas-Schoonen, K. T., et al. (1999). Missing lithotroph identified as new planctomycete. Nature 400, 446-449. doi: 10.1038/22749

Sun, W., Xu, M., Wu, W. M., Guo, J., Xia, C., Sun, G., et al. (2013). Molecular diversity and distribution of anammox community in sediments of the dongjiang river, a drinking water source of Hong Kong. J. Appl. Microbiol. 116, 464-476. doi: 10.1111/jam.12367

Trimmer, M., Nicholls, J. C., and Deflandre, B. (2003). Anaerobic ammonium oxidation measured in sediments along the thames estuary, United Kingdom. Appl. Environ. Microbiol. 69, 6447-6454. doi: 10.1128/AEM.69.11.6447-6454. 2003 
Wang, J., Dong, H., Wang, W., and Gu, J. D. (2014). Reverse-transcriptional gene expression of anammox and ammonia-oxidizing archaea and bacteria in soybean and rice paddy soils of northeast China. Appl. Microbiol. Biotechnol. 98, 2675-2686. doi: 10.1007/s00253-013-5242-x

Wang, J., and Gu, J. D. (2013). Dominance of Candidatus Scalindua species in anammox community revealed in soils with different duration of rice paddy cultivation in northeast China. Appl. Microbiol. Biotechnol. 97, 1785-1798. doi: 10.1007/s00253-012-4036-x

Wang, S., Hong, Y., Wu, J., Xu, X. R., Bin, L., Pan, Y., et al. (2015). Comparative analysis of two 16S rRNA gene-based PCR primer sets provides insight into the diversity distribution patterns of anammox bacteria in different environments. Appl. Microbiol. Biotechnol. 99, 8163-8176. doi: 10.1007/s00253-0156814-8

Wang, S., Zhu, G., Peng, Y., Jetten, M. S. M., and Yin, C. (2012). Anammox bacterial abundance, activity, and contribution in riparian sediments of the pearl river estuary. Environ. Sci. Technol. 46, 8834-8842. doi: 10.1021/es30 17446

Wilson, M. J., He, Z., and Yang, X. (2004). The Red Soils of China. Alphen aan den Rijn: Kluwer Academic Publishers. doi: 10.1007/978-1-4020-2138-1

Woebken, D., Lam, P., Kuypers, M. M., Naqvi, S. W., Kartal, B., Strous, M., et al. (2008). A microdiversity study of anammox bacteria reveals a novel Candidatus Scalindua phylotype in marine oxygen minimum zones. Environ. Microbiol. 10, 3106-3119. doi: 10.1111/j.1462-2920.2008.01640.x

Wu, J., Hong, Y., Guan, F., Wang, Y., Tan, Y., Yue, W., et al. (2016). A rapid and high-throughput microplate spectrophotometric method for field measurement of nitrate in seawater and freshwater. Sci. Rep. 6:20165. doi: 10.1038/srep20165

Xi, D., Bai, R., Zhang, L., and Fang, Y. (2016). Contribution of anammox to nitrogen removal in two temperate forest soils. Appl. Environ. Microbiol. 82, 4602-4612. doi: 10.1128/AEM.00888-16

Xu, R., Zhao, A., Li, Q., Kong, X., and Ji, G. (2003). Acidity regime of the Red Soils in a subtropical region of southern China under field conditions. Geoderma 115 , 75-84. doi: 10.1016/S0016-7061(03)00077-6

Yang, X. R., Li, H., Nie, S. A., Su, J. Q., Weng, B. S., Zhu, G. B., et al. (2015). Potential contribution of anammox to nitrogen loss from paddy soils in southern China. Appl. Environ. Microbiol. 81, 938-947. doi: 10.1128/AEM.02664-14
Yang, X. R., Weng, B. S., Li, H., Marshall, C. W., Li, H., Chen, Y. S., et al. (2017). An overlooked nitrogen loss linked to anaerobic ammonium oxidation in estuarine sediments in China. J. Soils Sediments 17, 2537-2546. doi: 10.1007/s11368-0171728-y

Yoshinaga, I., Amano, T., Yamagishi, T., Okada, K., Ueda, S., Sako, Y., et al. (2011). Distribution and diversity of anaerobic ammonium oxidation (anammox) bacteria in the sediment of a eutrophic freshwater lake, lake kitaura, Japan. Microbes Environ. 26, 189-197. doi: 10.1264/jsme2.ME10184

Zhang, W., Xu, M., Wang, B., and Wang, X. (2009). Soil organic carbon, total nitrogen and grain yields under long-term fertilizations in the upland red soil of southern China. Nutr. Cycling Agroecosyst. 84, 59-69. doi: 10.1007/s10705008-9226-9227

Zhao, Y., Xia, Y., Kana, T. M., Wu, Y., Li, X., and Yan, X. (2013). Seasonal variation and controlling factors of anaerobic ammonium oxidation in freshwater river sediments in the taihu lake region of China. Chemosphere 93, 2124-2131. doi: 10.1016/j.chemosphere.2013.07.063

Zheng, Y., Jiang, X., Hou, L., Liu, M., Lin, X., Gao, J., et al. (2016). Shifts in the community structure and activity of anaerobic ammonium oxidation bacteria along an estuarine salinity gradient. J. of Geophys. Res. Biogeosci. 121, 1632-1645. doi: 10.1002/2015JG003300

Zhu, G., Wang, S., Wang, Y., Wang, C., Risgaardpetersen, N., Jetten, M. S., et al. (2011). Anaerobic ammonia oxidation in a fertilized paddy soil. ISME J. 5, 1905-1912. doi: 10.1038/ismej.2011.63

Conflict of Interest Statement: The authors declare that the research was conducted in the absence of any commercial or financial relationships that could be construed as a potential conflict of interest.

Copyright (C) 2018 Wu, Hong, He, Jiao, Wen, Chen, Chen, Li, Huang, Hu and Liu. This is an open-access article distributed under the terms of the Creative Commons Attribution License (CC BY). The use, distribution or reproduction in other forums is permitted, provided the original author(s) and the copyright owner(s) are credited and that the original publication in this journal is cited, in accordance with accepted academic practice. No use, distribution or reproduction is permitted which does not comply with these terms. 